\title{
FEATURE
}

\section{The nitrogen dilemma: Food or the environment}

\author{
B.A. Stewart and Rattan Lal
}

$\mathbf{N}$ itrogen $(\mathrm{N})$ is the most important essential element for crop production because it is required in large amounts and is nearly always the first nutrient that becomes limiting after an ecosystem is converted to cropland. Cereal grains provide about $50 \%$ of the world's calories, and their production has become largely dependent on the use of synthetic $\mathrm{N}$ fertilizer. However, fertilizer $\mathrm{N}$ not used by plants can degrade the environment and negatively impact both people and ecosystems. In addition, efficient use of $\mathrm{N}$ fertilizer generally requires phosphorus $(\mathrm{P})$ fertilizer which is made from rock phosphate derived from mines. Therefore, huge amounts of $\mathrm{N}$ and $\mathrm{P}$ from outside sources are being added to the environment each successive year leading to additional environmental concerns.

\section{RISE IN NITROGEN FERTILIZER USE}

By the early 1800s, it was becoming increasingly clear that there was a great need for $\mathrm{N}$ fertilizers. Europeans began importing guano (solidified bird excrement) and sodium nitrate $\left(\mathrm{NaNO}_{3}\right)$ from South America (Smil 2001), but it became apparent that supplies of these $\mathrm{N}$ sources would be insufficient. Coal contains between $1 \%$ and $1.6 \% \mathrm{~N}$, derived from the decomposition of proteins that were present in the biomass that was eventually transformed by pressure and heat to produce the solid fuel (Smil 2001). When burned in the absence of air, part of the $\mathrm{N}$ is released as ammonia $\left(\mathrm{NH}_{3}\right)$ and can be converted to ammonium sulfate $\left(\left[\mathrm{NH}_{4}\right]_{2} \mathrm{SO}_{4}\right)$ for use as a fertilizer. This process was practiced in western Europe in the 1860s and 1870s (Smil 2001).

B.A. Stewart is a distinguished university professor of soil science at the West Texas A\&M University, Canyon, Texas. He is also the director of the Dryland Agriculture Institute. Rattan Lal is a distinguished university professor of soil science and the director of the Carbon Management and Sequestration Center at the Ohio State University, Columbus, Ohio.
It was not, however, until the end of World War II in 1945 that $\mathrm{N}$ fertilizers became plentiful and economical. This was the result of the invention of Fritz Haber in 1909 that synthesized $\mathrm{N}$ and hydrogen $\left(\mathrm{H}_{2}\right)$ to produce $\mathrm{NH}_{3}$. Carl Bosch rapidly industrialized this process, known as the Haber-Bosch process, that combines $\mathrm{N}$ from the air with $\mathrm{H}_{2}$ from an energy source under high pressure. This invention is considered one of the most important of all time, and both Haber and Bosch received Nobel Prizes. The process was widely used during both World War I and World War II to make munitions. Many $\mathrm{NH}_{3}$ plants were constructed during World War II, and when the war ended, they were rapidly converted to produce fertilizer rather than munitions, so $\mathrm{N}$ fertilizer became readily available and relatively inexpensive.

The yields of wheat (Triticum aestivum L.), maize (Zea mays L.), and rice (Oryza sativa) increased rapidly, and the amounts of $\mathrm{N}$ fertilizer applied to cropland increased even faster. Between 1961 and 2014, worldwide grain production increased 4-fold, but the amount of $\mathrm{N}$ fertilizer used increased almost 10 times (FAOSTAT 2017). During the same time period, world population increased from 3.1 billion to 7.3 billion, and it is expected to reach 9.8 billion by 2050 (table 1). Cereal crops use large amounts of fertilizer, and it has been estimated that synthetic $\mathrm{N}$ is responsible for feeding more than $50 \%$ of the world population; without it, the world population could not have increased to the level it has (Smil 1999, 2001; Erisman et al. 2008).

The benefits of $\mathrm{N}$ fertilizer were quickly recognized worldwide and played a major role in reducing world hunger and malnutrition. Much of the success of the Green Revolution led by Nobel Laureate Norman Borlaug that is credited for saving millions of lives during the 1960s was attributed to $\mathrm{N}$ fertilizer, which enhanced productivity of the high yielding dwarf varieties of rice and wheat with a high harvest index.

\section{IMPACTS OF SYNTHETIC NITROGEN FERTILIZER}

Little or no concern about possible negative effects of synthetic $\mathrm{N}$ fertilizer was shown during the 1950s and early 1960s. Barry Commoner of St. Louis University was perhaps the most vocal critic. He later authored a widely read book, The Closing Circle (Commoner 1971). Commoner stated that the widespread use of $\mathrm{N}$ fertilizer in the US Corn Belt was resulting in high concentrations of nitrate $\left(\mathrm{NO}_{3}\right)$ in water supplies that cause methemoglobinemia (blue-baby syndrome) in infants. The last thing the agricultural community wanted to hear, and what they refused to believe, was that the use of $\mathrm{N}$ fertilizer degraded the environment. This led to years of numerous conflicts between agriculturalists and environmentalists.

It is clearly recognized now, however, by the agricultural community as well as the environmental community that the use of $\mathrm{N}$ fertilizer is causing serious environmental issues in many parts of the world. Furthermore, the negative effects resulting from $\mathrm{N}$ fertilizer use are two-pronged. Phosphorus is usually second only to $\mathrm{N}$ as a limiting nutrient for crop production, so when $\mathrm{N}$ fertilizer eliminated $\mathrm{N}$ deficiency, widespread use of $\mathrm{P}$ fertilizer immediately followed. Phosphorus is also causing serious water quality problems such as hypoxia and the algal bloom. Most crops need about one part P for every five parts $\mathrm{N}$, so $\mathrm{N}$ and $\mathrm{P}$ fertilizers are commonly added at a similar ratio. In 2014, 108.9 million $\mathrm{t}(120$ million $\mathrm{tn})$ of $\mathrm{N}$ and 20.5 million $\mathrm{t}(22.6$ million $\mathrm{tn})$ of $\mathrm{P}$ were applied worldwide in fertilizer (table 1). Maize, rice, and wheat account for $90 \%$ of the production of all cereal grains and are commonly fertilized with $\mathrm{N}$ and $\mathrm{P}$. In 2014, 2,819 million $\mathrm{t}$ (3,107 million tn) of these cereal grains were produced (FAOSTAT 2017). Assuming an average $\mathrm{N}$ concentration of $1.6 \%$ and a $\mathrm{P}$ concentration of $0.33 \%$ in the grains, the amounts of $\mathrm{N}$ and $\mathrm{P}$ removed with the grain were 45 million $\mathrm{t}(50$ million tn) and 8.3 million $\mathrm{t}$ (9.1 million $\mathrm{t})$, respectively. Thus, there 


\section{Table 1}

Temporal changes in population, cereal production, fertilizer nitrogen $(\mathrm{N})$, and gaseous emissions.

\begin{tabular}{|c|c|c|c|c|c|c|c|}
\hline Year & $\begin{array}{l}\text { World population } \\
\text { (billions)* }\end{array}$ & $\begin{array}{l}\text { Undernourished } \\
\text { people (millions)* }\end{array}$ & $\begin{array}{l}\text { Production } \\
\text { cereals (million } \mathrm{t}) \dagger\end{array}$ & $\begin{array}{l}\text { Arable land } \\
\text { (million ha)* }\end{array}$ & $\begin{array}{l}\text { Irrigated land } \\
\text { (million ha)‡ }\end{array}$ & $\begin{array}{l}\mathrm{N} \text { fertilizer } \\
\text { use (million } \mathrm{t} \text { )* }\end{array}$ & $\begin{array}{l}\mathrm{N}_{2} \mathrm{O} \text { emissions } \\
\left(t \mathrm{CO}_{2} \text { eq) } \dagger\right.\end{array}$ \\
\hline 1961 & 3.08 & - & 741 & 1,292 & 140 & 12.9 & - \\
\hline 1970 & 3.68 & - & 1,005 & 1,343 & 170 & 33.3 & $2.2259 \times 10^{6}$ \\
\hline 1990 & 5.31 & 101.7 & 1,714 & 1,409 & 250 & 80.8 & $2.9530 \times 10^{6}$ \\
\hline 2000 & 6.13 & 924.3 & 2,054 & 1,400 & 285 & 85.7 & $2.9205 \times 10^{6}$ \\
\hline
\end{tabular}

Notes: $\mathrm{N}_{2} \mathrm{O}=$ nitrous oxide. $\mathrm{CO}_{2}$ eq = equivalent carbon dioxide.

*Data from FAOSTAT (2017).

†Data from World Bank (2017).

‡Data from Siebert et al. (2015) and Worldwatch Institute (2012).

were about 2.5 times more $\mathrm{N}$ and $\mathrm{P}$ added worldwide in fertilizer than removed with the three cereal crops.

About $48 \%$ of the world's grain supply is consumed directly by humans and accounts for $48 \%$ of their calories (Worldwatch Institute 2016). Nearly all rice is consumed directly by humans, but approximately $17 \%$ of the wheat and $35 \%$ of the maize are fed to animals (Worldwatch Institute 2016). Because of increasing demand for animal-based protein in developing countries with increasing prosperity, maize production is rapidly increasing in comparison to wheat and rice. From 1961 to 2000, annual production amounts of these cereal crops were almost equal, but in 2014, maize production was more than 1,000 million $\mathrm{t}(1,100$ million $\mathrm{tn})$ compared to about 750 million $t$ (827 million tn) each for rice and wheat. Maize demand increased because increasing prosperity in developing countries led to many people changing diets that included more animal based protein. Large amounts of maize, particularly in the United States, were also used for ethanol production. The Food and Agriculture Organization of the United Nations (FAO) stated that the world population would increase by one-third between 2009 and 2050, but overall food and fiber production would need to increase by $70 \%$ (FAO 2009). In 2009 , commercial fertilizer was responsible for $40 \%$ to $60 \%$ of the world's food production (Roberts 2009). Essentially all of future increases in grain production will depend on added fertilizer because the amount of cropland is not expected to increase significantly; yields per unit of cropland must increase requiring higher rates of $\mathrm{N}$ and $\mathrm{P}$ fertilizers.

\section{WHAT IS THE DILEMMA?}

The "nitrogen dilemma" that has also resulted in a "phosphorus dilemma" is that huge amounts of $\mathrm{N}$ from an outside source are being introduced into the environment each year. Between 1961 and 2014, 3,544 million $\mathrm{t}$ (3,907 million tn) of $\mathrm{N}$ and 731 million $\mathrm{t}$ (806 million $\mathrm{tn}$ ) of $\mathrm{P}$ in commercial fertilizers were added to cropland that is an integral part of the environment (FAOSTAT 2017). The N was fixed $\mathrm{N}$ from the atmosphere that increased the total reactive $\mathrm{N}(\mathrm{Nr})$ of the world. Although the addition of $\mathrm{Nr}$ significantly increased food production, much of it was not used by plants. For example, Nebraska scientists (Cassman et al 2002) measured the difference between $N$ uptake in fertilized and unfertilized maize plots in 55 farmer fields in the north central United States and found only 37\% of the added $\mathrm{Nr}$ in the aboveground biomass. The $\mathrm{P}$ added with commercial fertilizer is derived from mines, so this is also introducing huge amounts of $\mathrm{P}$ each year from an outside source that can impact the environment. Fertilizer N can be volatilized as $\mathrm{NH}_{3}$ and deposited with precipitation in unwanted areas. It can also be converted to $\mathrm{NO}_{3}$ and then denitrified to nitrous oxides that are greenhouse gases (GHGs), or the $\mathrm{NO}_{3}$ can be leached to degrade water supplies, or move with runoff water and accelerate eutrophication and hypoxia in lakes, rivers, and the ocean. Likewise, $\mathrm{P}$ added with fertilizer is readily adsorbed by soil particles and moves with runoff water to pollute lakes and streams.

While the uses of $\mathrm{N}$ and $\mathrm{P}$ fertilizers are closely linked, the dominant sources are vastly different. Since the Haber-Bosch process fixes $\mathrm{N}$ from the atmosphere, and the atmosphere contains $78 \% \mathrm{~N}$, there will never be a shortage of $\mathrm{N}$ fertilizer as long as there is available energy. In contrast, the dominant source of $\mathrm{P}$ is rock phosphate that is a finite source found in mines. The estimated amounts in reserve vary widely, but $90 \%$ of the world's known reserves are controlled by five countries: Morocco, Jordan, South Africa, the United States, and China, with Morocco's share accounting for about $70 \%$ and the United States's for about $2 \%$ (Stewart et al. 2017).

Translocation of $\mathrm{N}$, along with $\mathrm{P}$, also plays a major role in the $\mathrm{N}$ dilemma. More than $50 \%$ of the world's fertilizer is added to wheat, rice, and maize (FAO 2000 ), and $35 \%$ of the maize is fed to animals (Worldwatch Institute 2016). Historically, animals consumed feedstuff and the manure remained on the land to recycle the nutrients. Simply stated, the animals moved to the feed whereas in recent decades the feed is increasingly being moved to the animals. Large concentrated animal feeding operations have become common where dairy cows and beef, swine, and poultry animals are fed maize and other feedstuffs to produce animal protein. These operations are 
often far removed from where the feed was produced, and the products are then shipped to urban areas for consumption. However, $50 \%$ to $70 \%$ of the $\mathrm{N}$ and $65 \%$ to $75 \%$ of the $\mathrm{P}$ consumed by the animals are excreted in urine and manure that stays in the area where the animals are fed (Lory et al. 2006; van Heugten and van Kempen 2017). The large amounts of manure produced are generally not used efficiently because many concentrated animal feeding operations are located in areas of limited cropland. Translocation of nutrients is not simply a US issue, but a worldwide concern because large animal feeding operations have spread to many countries as the demand for animal protein increased. The Netherlands serves as an example of adverse effects of excess $\mathrm{N}$ contributing to the $\mathrm{N}$ dilemma. Although the Netherlands is a small country, it is second only to the United States in the world for the export of agricultural products (Netherlands Worldwide 2017). The Netherlands produces large amounts of meat, dairy products, and eggs, but roughly $70 \%$ is exported. Maize and soybeans (Glycine max) are among the main feedstuffs, and they are largely imported. From 2014 to 2016, 5 million $t$ (5.5 million tn) of maize were imported compared to only 200,000 Mg (220,500 tn) produced. Also, most of the soybeans are imported. In 2009, the Netherlands was the second largest importer of soybeans in the world (Dutch Soy Coalition 2009).

\section{WHY DOES THE NITROGEN DILEMMA DEFY A SOLUTION?}

The widespread use of synthetic $\mathrm{N}$ fertilizer began around 1950 with little thought that there would be negative effects on the environment. However, for more than 50 years, it has been well documented that excess $\mathrm{N}$ is associated with water quality, GHGs, and human health. Countless experiments and computer simulation models have addressed the problem, and while there have been many outstanding accomplishments, the problems associated with the use of synthetic $\mathrm{N}$ fertilizer are considered by many to become more serious with each succeeding year.

The generalized response curve between increasing yield with increasing
$\mathrm{N}$ fertilizer is not linear, but curvilinear. The amount of yield increase becomes less with each succeeding unit of $\mathrm{N}$ fertilizer added until the maximum yield is obtained. Because of this relationship, a statement often heard at conferences is "If producers would cut the rate of $\mathrm{N}$ applied by $10 \%$, the pollution caused by excess $\mathrm{N}$ could be reduced by 50 percent." While one can quibble about the accuracy of the numbers, the statement is basically valid. This is in effect saying that farmers can largely solve the $\mathrm{N}$ dilemma in a simple manner. The reason the farmer does not do this is that the amount of $\mathrm{N}$ needed by the crop is not known because it is not known how much water will be available for the crop. The amount of $\mathrm{N}$ does not determine the yield. The yield of a grain crop can be expressed by the following equation (Stewart and Peterson 2015):

$\mathrm{GY}=\mathrm{ET} \times \mathrm{T} / \mathrm{ET} \times 1 / \mathrm{TR} \times \mathrm{HI}$,

where GY is dry grain yield $\left(\mathrm{kg} \mathrm{ha}^{-1}\right)$; ET is evapotranspiration $\left(\mathrm{kg} \mathrm{ha}^{-1}\right.$; water use by evaporation from soil surface and transpiration by the crop between seeding and harvest); T/ET is the fraction of evapotranspiration transpired by the crop; TR is the transpiration ratio (number of kilograms water transpired to produce $1 \mathrm{~kg}$ [2.2 lb] of aboveground biomass); and $\mathrm{HI}$ is the harvest index (kilograms dry grain/ kilograms aboveground dry biomass). This equation is similar to one presented in 2014 (Fischer et al. 2014) and applies to all situations where grain crops are produced.

Nitrogen is not a factor in equation 1, yet it is clear that $\mathrm{N}$ affects yield but only as it affects one or more of the other factors. The factors included in the equation have specific numbers for every situation. Phosphorus, diseases, insects, and countless other factors also affect GY but again only as they affect one of the factors included in the equation. For example, $\mathrm{N}$ affects plant vigor which can influence rooting depth to extract more water. It can affect how quickly a plant canopy develops to shade the ground, which will reduce evaporation from the soil surface and increase the $\mathrm{T} /$ ET factor. It can increase grain filling that will increase the HI. In the final analysis, however, the equation clearly shows that it is water that determines yield, and the amount of water available for a crop is beyond control of the farmer, even if the crop is irrigated. This is because it is only the amount of water transpired by the growing crop that determines the amount of biomass produced by photosynthesis, and this is affected not only by the amount of water available but on other climatic factors such as temperature, radiation, humidity, and wind. Most irrigated crops get a significant amount of their water from growing season rainfall, and the amount of rainfall for a given year also affects humidity and other climatic factors.

Even as complex as not knowing how much water will be available to the crop is not knowing the amount of $\mathrm{N}$ supplied to the growing crop from mineralization of soil organic matter (SOM) and, in some cases, from deposition with rainfall. Therefore, farmers never know with certainty how much $\mathrm{N}$ fertilizer will be required because yields from year to year are highly erratic, particularly in areas of limited growing season precipitation. Even in favorable environments, yield variations of $20 \%$ are common, and in low rainfall areas, the GYs often range from zero to three times average. Because $\mathrm{N}$ is usually the first limiting factor other than water, most farmers want to make sure they have enough $\mathrm{N}$ available to fully utilize the water. If we assume a farmer reduces the estimated fertilizer requirement by $10 \%$, and the yield is reduced by $5 \%$, the profit of the farmer may be reduced by $20 \%$, $30 \%$, or even more. This is because even though the reduced yield is rather small, it may be a large part of the profit because the only added cost was the N. All other input costs remain the same as well as harvest costs and fixed costs, so the farmer is very reluctant to allow $\mathrm{N}$ to limit production even for a "normal" year, and most farmers want to capitalize on that good year that occurs only so often. Therefore, it is not realistic to expect a farmer to voluntarily cut back on an input that is so important to potential profit.

\section{CONSEQUENCES OF THE NITROGEN DILEMMA}

Excess $\mathrm{N}$ degrades the environment in several ways. The atmosphere can be affected 
by $\mathrm{NH}_{3}$ volatilization and denitrification that emits nitrous oxides which are GHGs. The most serious concerns, however, have been focused on water quality issues. Excess $\mathrm{P}$ is also primarily a water quality issue. This makes excess nutrients more of a local issue than a global issue like GHGs. An agricultural practice that contributes GHGs to the atmosphere affects the entire world but has no immediate impact locally. In contrast, excess nutrients can affect only a local site, a small watershed, a river basin, a river, or some part of the ocean. Therefore, the manner in how the public reacts to environmental concerns differs greatly.

As already stated, the agricultural community, as well as the environmental community, agrees that the widespread use of chemical fertilizers is affecting water quality. And while fertilizer use efficiency has increased because of improved technologies, the problems in some cases become greater simply because of the cumulative amounts of $\mathrm{N}$ and $\mathrm{P}$ being added to the environment.

The agricultural community is almost universally opposed to regulations of any kind, and with water quality problems being somewhat localized, there have been few attempts to regulate the application of $\mathrm{N}$ and $\mathrm{P}$ although many guidelines have been established. The likely possibility of regulations will increase if and when localized water quality problems are perceived by the local residents as a serious health hazard. In the United States, two recent incidents are of interest. The City of Des Moines, Iowa, gets water from the Raccoon River for treatment and use by the nearly 500,000 residents. The US Safe Water Drinking Standards require that $\mathrm{NO}_{3}$ cannot be

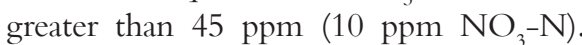
In recent years, the concentration in water pumped from the rivers frequently exceeds this amount making it necessary for the treatment plant to use expensive methods to remove some of the $\mathrm{NO}_{3}$. The cause of the $\mathrm{NO}_{3}$ is considered extensive use of $\mathrm{N}$ fertilizer and the high concentration of swine production facilities in Calhoun, Buena Vista, and Sac counties. In 2015, the Des Moines Water Works filed one of the first lawsuits in the United States for pollution from agricultural watersheds. Although the suit was scheduled to go to trial in 2016, it was postponed. On January 27, 2017, the Iowa Supreme Court ruled against the Des Moines Water Works lawsuit, determining that Iowa's water quality problems are an issue for the Iowa legislature to resolve (Maricle 2017).This illustrates the difficulty, but most likely not the end, of regulating the use of chemical fertilizers to control or prevent degradation of water quality.

A second incident occurred on August 3, 2014, when Toledo, the second largest city in Ohio, issued a "Do Not Drink" advisory for 400,000 residents served by the city water system. Chemical tests confirmed the presence of unsafe levels of the algal toxin Microcystin in the plant's treated water (Spear 2014). Harmful algal blooms in Lake Erie, one of the five Great Lakes of the United States, had become so highly concentrated that the toxin in the water entering the city treatment facility reached unsafe levels. The filtering system did not remove the toxin and boiling the water did not affect it, so the residents were without drinking water and also advised not to bathe in the water. The cause of the algal bloom was largely considered excess $\mathrm{P}$ from fertilized cropland in the watershed of the lake. Even if $\mathrm{N}$ is limited, $\mathrm{P}$ can cause algal blooms because there are algae that can fix $\mathrm{N}$ from the atmosphere. However, if there are both $\mathrm{N}$ and $\mathrm{P}$ present in the runoff water, the algae blooms can occur much faster and at a higher concentration. This again shows the close linkage between $\mathrm{N}$ and $\mathrm{P}$ fertilizers; the increased use of $\mathrm{N}$ fertilizer is almost always accompanied by increased use of $\mathrm{P}$ fertilizer.

\section{THE NITROGEN DILEMMA IS A POLICY ISSUE, NOT A SCIENTIFIC PROBLEM}

The Haber-Bosch process that synthesizes $\mathrm{NH}_{3}$ from $\mathrm{N}_{2}$ in the atmosphere and $\mathrm{H}_{2}$ using high temperature is without question one of the most significant scientific achievements ever. This resulted in readily available fertilizer at relatively affordable cost that allowed rapid and significant increases in food production. Between 1961 and 2016, the world population increased from 3 billion to more than 7.4 billion people (United Nations 2017). It is unlikely that the population could have increased to this level without $\mathrm{N}$ fertilizer, and the expected increase to 9.8 billion people by 2050 will be almost totally dependent on the continued use of synthetic $\mathrm{N}$ fertilizer. This will also require increasing amounts of $\mathrm{P}$ fertilizer made from rock phosphate coming from mines. Thus, huge amounts of these nutrients from outside sources will be added each succeeding year to the environment making it exceedingly difficult to prevent their movement to ground and surface waters causing serious environmental problems

Although the $\mathrm{N}$ dilemma is clearly an international problem, the effects are generally localized. Therefore, while the scientific community needs to continue developing more efficient methods for applying and utilizing fertilizer, science cannot develop a solution. In all likelihood, solutions will come only after people affected in localized areas become concerned enough to demand change, most likely through regulations or mandated practices They must also be willing to accept the consequences of what these changes may bring. Success in localized areas may eventually spread to other areas, but the solution for each area will be different because every ecosystem is unique.

\section{REFERENCES}

Cassman, K.G., A.R. Dobermann, D.T. Walters. 2002 Agroecosystems, nitrogen-use efficiency, and nitrogen management. Ambio 31:132.

Commoner, B. 1971. The Closing Circle. New York: Knopf.

Dutch Soy Coalition. 2009. Strategies for Reducing the Negative Effects of Soy Production. http://141.105.120.208/dsc/wp-content/ uploads/2014/04/Factsheet-1-Strategies-forreducing-the-negative-effects-of-soy-productionResponsible-soy-production.pdf.

Erisman, J.W., M.A. Sutton, J.N. Galloway, Z. Klimont, and W. Winiwarter. 2008. How a century of ammonia synthesis changed the world. Nature Geoscience 1:636.

FAO (Food and Agriculture Organization of the United Nations). 2000. Fertilizer Requirements in 2015 and 2030. Rome: FAO. ftp://ftp.fao.org/ agl/agll/docs/barfinal.pdf.

FAO. 2009. Global Agriculture Towards 2050 September 23, 2009. Rome: FAO. http://www. fao.org/news/story/en/item/35571/icode/.

FAOSTAT (Food and Agriculture Organization of the United Nations). 2017. Food and Agriculture 
Organization Corporate Statistical Database Statistics Division. Rome: FAO.

Fischer, R.A., D. Byerlee, and G.O. Edmeades. 2014. Crop Yields and Global Security: Will Yield Increase Continue to Feed the world? ACIAR Monograph. Canberra, Australia: Australian Centre for International Agricultural Research.

Lory, J.A., K.C. Olson, and C. Zumbrunnen. 2006. Calculating fertilizer value of supplemental feed for cattle on pasture. MU Guide G 2083. Columbia, MO: University of Missouri Extension, University of Missouri, Columbia. http://extension.missouri.edu/explorerpdf/ agguides/ansci/g2083.pdf.

Maricle, K. 2017. Supreme Court rules against Des Moines Water Works lawsuit over nitrates. WHO TV. January 27, 2017. http://whotv. com/2017/01/27/supreme-court-rules-againstdes-moines-water-works-lawsuit-over-nitrates/.

Netherlands Worldwide. 2017. The Netherlands: The world's second largest exporter of agrifood. Netherlands Worldwide. October 6, 2016. https://www.netherlandsworldwide.nl/latest/ news/2016/06/10/the-netherlands-the-worlds-second-largest-exporter-of-agri-food.

Roberts, T.L. 2009. The role of fertilizer in growing the world's food. Better Crops 93(2):12-15. https://ipni.net/ppiweb/bcrops.nsf/\$webindex /0022BBC19C02604A852575C50062FBB7/\$f ile/BC09-2p12.pdf.

Siebert, S., M. Kummu, M. Porkka, P. Döll, N. Ramankutty, and B.R. Scanlon. 2015. A global data set of the extent of irrigated land from 1900 to 2005. Hydrology and Earth System Sciences 19:1521.

Smil,V. 1999. Detonator of the population explosion. Nature 400, 415.

Smil, V. 2001. Enriching the Earth: Fritz Haber, Carl Bosch, and the Transformation of World Food Production. Boston: MIT Press.

Spear, S. 2014. Toxic algae bloom leaves 500,000 without drinking water in Ohio. Circle of Blue. August 3, 2014. https://www.ecowatch.com/ toxic-algae-bloom-leaves-500-000-withoutdrinking-water-in-ohio-1881940537.html.

Stewart, B.A., and G.A. Peterson. 2015. Managing green water in dryland agriculture. Agronomy Journal 107:1544.

Stewart, B.A., P. Pokhrel, and M. Bhandari. 2017. Soil Phosphorus, p. 23-43. Boca Raton, FL: CRC Press.

United Nations. 2017. World Population Prospects: Key Findings and Advance Tables. New York: United Nations Economic and Social Affairs.

van Heugten, E., and T. van Kempen. 2017. Understanding and Applying Nutrition Concepts to Reduce Nutrient Excretion in Swine. Raleigh, NC: North Carolina State University. https:// projects.ncsu.edu/project/swine_extension/ nutrition/environ/concepts.pdf.

World Bank. 2017. Indicators. https://data.worldbank.org/indicator/.

Worldwatch Institute. 2012. Global irrigated area at record levels, but expansion slowing. November
27, 2012. http://www.worldwatch.org/ global-irrigated-area-record-levels-expansionslowing-0.

Worldwatch Institute. 2016. Pesticides pose risk in rural and urban communities alike. http://www. worldwatch.org/node/5359. 